\title{
CYTOTOXIC AND GENOTOXIC POTENTIAL OF Ginkgo biloba L., IN INDUSTRIALIZED AND WITHOUT-ADDITIVE FORMS
}

\author{
POTENCIAL CITOTÓXICO E GENOTÓXICO DE Ginkgo biloba L., NAS FORMAS \\ INDUSTRIALIZADA E NÃO ADITIVADA
}

\begin{abstract}
Clarice Moura GUEDES ${ }^{\mathbf{1}}$; Fabelina Karollyne Silva dos SANTOS ${ }^{\mathbf{1}}$; Tamires de Sousa SILVA ${ }^{\mathbf{1}}$; Ana Paula SOARES E SILVA ${ }^{\mathbf{1}}$; Michele Vieira da Silva LIMA ${ }^{\mathbf{1}}$; Valtânia Ana de OLIVEIRA ${ }^{\mathbf{1}}$; Maria Eduarda Sousa e SILVA ${ }^{1}$; Maria Carolina de ABREU ${ }^{1}$; Ana Paula Paula PERON ${ }^{1,2}$

1. Laboratório de Citogenética e Mutagênese (LaCM). Campus Senador Helvídio Nunes de Barros (CSHNB). Universidade Federal do Piauí (UFPI). Picos, Piauí, Brazil, clariceguedes92@gmail.com; 2. Programa de Pós-graduação em Genética e Melhoramento (PPGM). Centro de Ciências Agrárias (CCA). Campus Ministro Petrônio Portella (CMPP). Universidade Federal do Piauí (UFPI). Teresina, Piauí, Brazil.
\end{abstract}

\begin{abstract}
The toxic potential at the cellular level of industrialized Ginkgo biloba L. leaves was evaluated in meristematic cells of Allium cepa at concentrations of $0.1 ; 0.2$ and $0.4 \mathrm{mg} / \mathrm{ml}$. The industrialized products, from four pharmaceutical laboratories, were identified as A, B, C and D. Cell-level toxicity of dehydrated ginkgo leaf tea was also evaluated at concentrations of $0.15 ; 0.30$ and $0.60 \mathrm{mg} / \mathrm{ml}$. Dehydrated products were purchased from herbalists certified by ANVISA. The roots were exposed to teas and processed products for 24 and 48 hours. The results were submitted to the Chi-square test at $5 \%$. However, industrialized ginkgo products at all concentrations caused antiproliferative effect. Also, the products purchased in pharmacies did not induce significant changes to root meristems. Therefore, industrialized ginkgo promoted cytotoxicity, however, they were not genotoxic to the bioassay used.
\end{abstract}

KEYWORDS: Ginkgo. Excipients. Cell division. Cellular changes. Meristematic tissue.

\section{INTRODUCTION}

Leaves of Ginkgo biloba L. (Family Ginkgoaceae), a species native to Eastern countries, such as China and Japan, have long been used for the treatment and prevention of cardiopulmonary dysfunctions, labyrinthitis and diseases triggered by senescence (POLANSKI et al., 2016; MAHMOUDIAN-SANI et al., 2017). This plant also has recognized antioxidant potential (HAMZAWY et al., 2015). It is popularly known as ginkgo or maidenhair tree, and has high concentrations of ginkgolide diterpenes, bilobalide sesquiterpenes, triterpenes, polyphenols, ginkgolide acids, flavones, flavonols and biflavonoids in the foliage (POLANSKI et al., 2016). This plant is worldwide marketed in herbal stores and drugstores, in dehydrated form and in tablets and/or capsules, respectively (MAHMOUDIAN-SANI et al., 2017; WANG et al., 2017). Tea of fresh ginkgo leaves was evaluated for its toxic potential at the cellular level, and it was verified that this plant was neither cytotoxic nor genotoxic to the bioassays used. Furthermore, fresh ginkgo was found to have a repairing effect on cell damage to tissues previously treated with clastogenic drugs (TURKEZ et al., 2014; HAMZAWY et al., 2015; OLIVEIRA et al., 2017).

In contrast to the non-industrialized form, the ginkgo available in tablets and/or capsules has in its composition additives or excipients, also referred to as inactive compounds, with dye, flavoring, sweetening, preservative, stabilizing, antioxidant, emulsifying, diluent actions, among others (ELDER et al., 2016). These chemical compounds do not possess therapeutic properties and are intentionally added to the drugs in order to make them palatable, stable, easily absorbed and protected from the action of microorganisms (ELDER et al., 2016; PATRA et al., 2016). In general, such ingredients are greater in volume relative to the active ingredients, and their concentrations in drugs may vary between pharmaceutical laboratories (HENG et al., 2014).

However, research such as Vasconcelos et al. (2012), Barros et al. (2015), Marek and Ktaft (2017) have shown that inactive ingredients can promote adverse reactions to the human body, especially to children, such as allergies, cardiovascular and respiratory problems, hyperactivity, light hypersensitivity and neurological problems. In addition, in Brazil, the Ministry of Health states that to date, because of the scarcity of studies, the excipients raise many questions about their potential toxic effects at the cellular level (BRASIL, 2007; MOURA et al., 2017). This government body also emphasizes in its technical documents the need to carry out studies that verify the cytotoxicity and genotoxicity of products added with excipients, claiming the 
urgency to ensure the safe consumption of medicines by the population.

The root meristem of Allium cepa $\mathrm{L}$. is considered an efficient test system for the initial screening of the cytotoxicity and genotoxicity of chemical compounds, occupying a prominent position among the set of tests used in the preliminary evaluation of cytotoxotoxic agents (HERRERO et al., 2012; MARTINS; PERON, 2017). The efficiency of the bioassay is mainly because this species presents few chromosomes $(2 \mathrm{n}$ $=16$ ), which favors the detection of disorders in the cell proliferation index, and cellular alterations, such as mitotic spindle disturbances and chromosomal breaks (NEVES et al., 2014; SALES et al., 2016). Furthermore, the $A$. cepa system is accepted internationally by research agencies since the results obtained show satisfactory similarity to those obtained with animal testing systems and in cell cultures (HERRERO et al., 2011; LACERDA et al., 2014; MOURA et al., 2016, SANTANA et al., 2016; SALES et al., 2016; SALES et al., 2017).

Therefore, considering the medicinal relevance of the leaves of $G$. biloba and the widespread consumption of this plant by the population, the goal was to evaluate in meristem root cells of $A$. cepa, the difference in toxicity at the cellular level of industrialized products based on ginkgo leaves or added with excipients and ginkgo products without industrialization.

\section{MATERIAL AND METHODS}

\section{Study material, preparation and definition of concentrations}

For the present study, tablets made from dry extract of $G$. biloba leaves from four different pharmaceutical laboratories, two national and two international - referred, for ethical reasons, to as A, $\mathrm{B}, \mathrm{C}$ and $\mathrm{D}$ - were obtained in a drugstore in the municipality of Teresina, State of Piauí, Brazil, representative of a national network of drugstores. According to information from which the industrialized products were acquired, the four brands evaluated are the most sold by the network to which the drugstore is part. Upon purchase, the drugstore had seven different brands of industrialized ginkgo products. It is important to mention that this network of drugstores has branches throughout Brazil.

In the form without additives, dried ginkgo leaves were obtained from two different herbal stores, one located in Teresina, State of Piauí, Brazil, and another located in the city of São Paulo, State of São Paulo, Brazil, both certified by
ANVISA and specialized for more than ten years in the marketing of natural products.

For the determination of the study concentrations, the amount and the form of consumption indicated in the labels of each product were used as parameter. For the industrialized ginkgo, it was suggested to take a $40 \mathrm{mg}$ tablet daily with $200 \mathrm{~mL}$ water (one glass of water). Thus, the baseline concentration was $0.2 \mathrm{mg} / \mathrm{mL}$, then we defined further two concentrations, 0.1 and 0.4 $\mathrm{mg} / \mathrm{mL}$. In preparation of the concentrations, the tablets were macerated, and the distilled water was added to the obtained powder at room temperature.

For the two commercial samples of ginkgo without additives, it was recommended to prepare tea with $30 \mathrm{mg}$ dried leaves (one teaspoon) in 1 liter boiling water. Thus, the first concentration established was $0.3 \mathrm{mg} / \mathrm{mL}$, and from this, two other concentrations, 0.15 and $0.6 \mathrm{mg} / \mathrm{mL}$ were established. It is important to mention that after preparation of the teas in distilled water, we waited to cool down to room temperature to start toxicity assessments.

\section{Assessment of cytotoxicity and genotoxicity in root meristem cells of Allium cepa $\mathbf{L}$.}

Initially, onion bulbs were placed in aerated flasks with distilled water to obtain roots $2.0 \mathrm{~cm}$ in length. For the analysis of all the concentrations (treatment), set an experimental group with five onion bulbs. Before placing the roots in contact with their respective treatments, some roots were collected and fixed to serve as control of the bulb itself, which was called analysis time 0 hour $(0 \mathrm{~h})$. Soon afterwards, the remaining roots were placed in their respective concentrations for 24 and 48 hours, procedures called exposure times 24 and $48 \mathrm{~h}$, where root collection was performed every 24 hours. A negative control with distilled water was also made, in which roots were also collected at times 0, 24 and $48 \mathrm{~h}$. Roots were fixed in Carnoy solution 3: 1 (ethanol: acetic acid) for $24 \mathrm{~h}$.

Slides were mounted according to the protocol proposed by Guerra and Souza (2002), and analyzed in an optical microscope with an objective lens of $40 \mathrm{x}$. For each bulb, 1,000 cells were analyzed, totaling 5,000 cells for each control group $(0 \mathrm{~h}), 24 \mathrm{~h}$ exposure time group and $48 \mathrm{~h}$ exposure time group. We counted cells in interphase and dividing cells, and calculated the mitotic index, which served as a parameter for the determination of cytotoxicity. In addition, we evaluated genotoxicity through the frequency of micronuclei, aneugenic or mitotic spindle alterations, through the frequency of colchicine metaphases, anaphase and telophase 
bridges, gene amplifications, cells with adhesions, nuclear buds and multipolar anaphases. Results referring to cytotoxicity and genotoxicity were evaluated according to the statistical Chi-square $(\chi 2)$ test at $5 \%$.

\section{RESULTS AND DISCUSSION}

Based on the results obtained (Table 1), the mitotic indices for the root meristems exposed to the three tea concentrations of the two ginkgo samples, at 24 and $48 \mathrm{~h}$ of exposure, were not significantly different from the observed division indices for their respective exposure times $0 \mathrm{~h}$, as well as to the indices of the distilled water control. The treatments also did not induce the formation of mitotic spindle and micronuclei in the analyzed meristematic tissues. Thus, under the conditions of analysis established, ginkgo without additives were neither cytotoxic nor genotoxic. The results of nontoxic action at the cellular level of ginkgo without industrialization obtained in the present study corroborate the results of non-cytotoxicity and nongenotoxicity of this plant found in the scientific literature, including the studies of Turkez et al. (2014), Hamzawy et al. (2015) and Oliveira et al. (2017).

Table 1. Mitotic indices observed in root meristematic tissues of Allium cepa exposed for 24 and $48 \mathrm{~h}$ to distilled water (negative control) and three concentrations of teas of two commercial samples of Ginkgo biloba leaves, without additives. In each treatment, the significant values of $\chi^{2}$ were presented.

\begin{tabular}{|c|c|c|c|c|c|}
\hline \multirow{4}{*}{ Co } & & ET & TCII & TCD & MI (\%) \\
\hline & & $\overline{\mathrm{CO}}$ & 2905 & 2095 & $41.9^{\mathrm{a}}$ \\
\hline & & $24 \mathrm{~h}$ & 2915 & 2085 & $41.7^{\mathrm{a}}$ \\
\hline & & $48 \mathrm{~h}$ & 2935 & 2065 & $41.3^{\mathrm{a}}$ \\
\hline $\begin{array}{l}\text { Ginkgo biloba PRODUCT } \\
(\mathrm{mg} / \mathrm{mL})\end{array}$ & $\begin{array}{l}\text { Concentration } \\
(\mathrm{mg} / \mathrm{mL})\end{array}$ & ET & TCII & TCD & MI (\%) \\
\hline \multirow{9}{*}{ Tea 1} & \multirow{3}{*}{0.15} & $\mathrm{CO}$ & 2990 & 2010 & $40.2^{\mathrm{a}}$ \\
\hline & & $24 \mathrm{~h}$ & 3091 & 1909 & $38.2^{\mathrm{a}}$ \\
\hline & & $48 \mathrm{~h}$ & 3105 & 1895 & $37.9^{\mathrm{a}}$ \\
\hline & \multirow{3}{*}{0.30} & $\mathrm{CO}$ & 3367 & 1633 & $32.7^{\mathrm{a}}$ \\
\hline & & $24 \mathrm{~h}$ & 3449 & 1551 & $31.1^{\mathrm{a}}$ \\
\hline & & $48 \mathrm{~h}$ & 3509 & 1491 & $29.9^{\mathrm{a}}$ \\
\hline & \multirow{3}{*}{0.60} & $\mathrm{CO}$ & 3464 & 1536 & $30.7^{\mathrm{a}}$ \\
\hline & & $24 \mathrm{~h}$ & 3591 & 1409 & $28.1^{\mathrm{a}}$ \\
\hline & & $48 \mathrm{~h}$ & 3624 & 1376 & $27.7^{\mathrm{a}}$ \\
\hline \multirow{9}{*}{ Tea 2} & \multirow{3}{*}{0.15} & $\mathrm{CO}$ & 3110 & 1890 & $37.8^{\mathrm{a}}$ \\
\hline & & $24 \mathrm{~h}$ & 3277 & 1723 & $34.5^{\mathrm{a}}$ \\
\hline & & $48 \mathrm{~h}$ & 3322 & 1678 & $33.5^{\mathrm{a}}$ \\
\hline & \multirow{3}{*}{0.30} & $\mathrm{CO}$ & 3019 & 1981 & $39.6^{\mathrm{a}}$ \\
\hline & & $24 \mathrm{~h}$ & 3123 & 1877 & $37.5^{\mathrm{a}}$ \\
\hline & & $48 \mathrm{~h}$ & 3157 & 1843 & $36.8^{\mathrm{a}}$ \\
\hline & \multirow{3}{*}{0.60} & $\mathrm{CO}$ & 3009 & 1991 & $39.8^{a}$ \\
\hline & & $24 \mathrm{~h}$ & 3133 & 1867 & $37.3^{\mathrm{a}}$ \\
\hline & & $48 \mathrm{~h}$ & 3168 & 1832 & $36.6^{\mathrm{a}}$ \\
\hline \multirow{10}{*}{ PL A } & \multirow{3}{*}{0.10} & $\mathrm{CO}$ & 2845 & 2155 & $43.1^{\mathrm{a}}$ \\
\hline & & $24 \mathrm{~h}$ & 4403 & 597 & $11.9^{b^{*}}$ \\
\hline & & $48 \mathrm{~h}$ & 4463 & 537 & $10.7^{b^{*}}$ \\
\hline & \multirow{3}{*}{0.20} & $\mathrm{CO}$ & 2905 & 2095 & $41.9^{\mathrm{a}}$ \\
\hline & & $24 \mathrm{~h}$ & 4603 & 397 & $7.9^{b^{*}}$ \\
\hline & & $48 \mathrm{~h}$ & 4649 & 351 & $7.0^{\mathrm{b}^{*}}$ \\
\hline & \multirow{4}{*}{0.40} & $\mathrm{CO}$ & 3060 & 1940 & $38.8^{\mathrm{a}}$ \\
\hline & & $24 \mathrm{~h}$ & 4785 & 215 & $4.3^{b^{*}}$ \\
\hline & & $48 \mathrm{~h}$ & 4803 & 197 & $3.9^{b^{*}}$ \\
\hline & & $\mathrm{CO}$ & 3340 & 1660 & $33.1^{a}$ \\
\hline
\end{tabular}




\begin{tabular}{|c|c|c|c|c|c|}
\hline \multirow{8}{*}{ PL B } & \multirow[t]{2}{*}{0.10} & $24 \mathrm{~h}$ & 4512 & 488 & $9.7^{b^{*}}$ \\
\hline & & $48 \mathrm{~h}$ & 4463 & 237 & $4.7^{\mathrm{b}^{*}}$ \\
\hline & \multirow{3}{*}{0.20} & $\mathrm{CO}$ & 2911 & 2089 & $41.8^{a}$ \\
\hline & & $24 \mathrm{~h}$ & 4620 & 380 & $7.6^{b^{*}}$ \\
\hline & & $48 \mathrm{~h}$ & 4711 & 289 & $5.8^{\mathrm{b}^{*}}$ \\
\hline & \multirow{3}{*}{0.40} & $\mathrm{CO}$ & 2723 & 2277 & $45.5^{\mathrm{a}}$ \\
\hline & & $24 \mathrm{~h}$ & 4509 & 491 & $9.8^{b^{*}}$ \\
\hline & & $48 \mathrm{~h}$ & 4701 & 299 & $6.0^{\mathrm{b}^{*}}$ \\
\hline \multirow{9}{*}{ PL C } & \multirow{3}{*}{0.10} & $\mathrm{CO}$ & 3003 & 1997 & $39,9^{a}$ \\
\hline & & $24 \mathrm{~h}$ & 4126 & 874 & $17,5^{\mathrm{a}^{*}}$ \\
\hline & & $48 \mathrm{~h}$ & 4267 & 733 & $14,7^{\mathrm{a}^{*}}$ \\
\hline & \multirow{3}{*}{0.20} & $\mathrm{CO}$ & 2977 & 2023 & $40,5^{a}$ \\
\hline & & $24 \mathrm{~h}$ & 4002 & 998 & $20,0^{\mathrm{b}^{*}}$ \\
\hline & & $48 \mathrm{~h}$ & 4106 & 894 & $17,9^{b^{*}}$ \\
\hline & \multirow{3}{*}{0.40} & $\mathrm{CO}$ & 2989 & 2011 & $40,2^{a}$ \\
\hline & & $24 \mathrm{~h}$ & 4077 & 923 & $18,5^{\mathrm{b}}$ \\
\hline & & $48 \mathrm{~h}$ & 4129 & 871 & $17,4^{b^{*}}$ \\
\hline \multirow{9}{*}{ PL D } & \multirow{3}{*}{0.10} & $\mathrm{CO}$ & 2959 & 2041 & $40,8^{\mathrm{a}}$ \\
\hline & & $24 \mathrm{~h}$ & 4026 & 974 & $19,5^{b^{*}}$ \\
\hline & & $48 \mathrm{~h}$ & 4121 & 879 & $17,6^{\mathrm{b}^{*}}$ \\
\hline & \multirow{3}{*}{0.20} & $\mathrm{CO}$ & 2737 & 2263 & $45,2^{\mathrm{a}}$ \\
\hline & & $24 \mathrm{~h}$ & 4057 & 943 & $18,8^{b^{*}}$ \\
\hline & & $48 \mathrm{~h}$ & 4108 & 892 & $17,8^{b^{*}}$ \\
\hline & \multirow{3}{*}{0.40} & $\mathrm{CO}$ & 2833 & 2167 & $43,3^{\mathrm{a}}$ \\
\hline & & $24 \mathrm{~h}$ & 4110 & 890 & $17,8^{b^{*}}$ \\
\hline & & $48 \mathrm{~h}$ & 4239 & 761 & $15,2^{b^{*}}$ \\
\hline
\end{tabular}

PL: pharmaceutical laboratory; Co: Distilled water control; ET: exposure time; TCII: Total number of cells in interphase and undifferentiated cells; TCD: Total number of dividing cells. Values followed by different letters, in the same treatment, are significantly different from each other by the $\chi 2$ test, at the $5 \%$ level. *Significant MI/ET of ginkgo to the specific MI/ET of the negative control. '

Differently, G. biloba from PL (pharmaceutical laboratory) A, B, C and D (Table 01 ), at $0.1 ; 0.2$ and $0.4 \mathrm{mg} / \mathrm{mL}$, at exposure times 24 and $48 \mathrm{~h}$, significantly reduced the cell division of meristematic tissues when compared to the mitotic indices obtained for their respective $0 \mathrm{~h}$ time and control with distilled water. However, the reduction in the cell division obtained for PL A and B was more pronounced than that observed for PL C and D.

According to Herrero et al. (2012), mitotic indices significantly lower than the negative control indices, such as those obtained for PL A, B, C and $\mathrm{D}$, may indicate the presence of agents whose toxic action compromises the growth and development of the exposed organisms. Furthermore, these authors state that the inhibition of cell proliferation triggered by cytotoxic compounds in tissues with high cell proliferation and normal performance, such as those used in the present study, is quite detrimental to the organism because it inhibits or limits the replacement of cells, proteins and result in malfunction of the organ.

There were no cellular alterations, in a significant number, in tissues exposed to PL A, B, C and D. Nevertheless, Sales et al. (2016) suggest that drastic inhibition of division in normal tissues may occur through the action of agents that affect the integrity of the mitotic spindle promoting chromosomal derangement. Considering that the principle of the cell cycle is the formation of identical cells, the production of new cells with significant change in structure and/or number of chromosomes make cell functioning unfeasible and tend to be eliminated from tissues with normal performance, which may lead to a significant antiproliferative effect.

Additionally, it is important to note that the package inserts of all industrialized ginkgo products inform the excipients used in the drugs were lactose (dispersant), corn starch (diluent), titanium dioxide and sunset yellow dye (dyes), bicalcium phosphate (flux agent), Eudragit $\mathrm{E}$ and ethanol (diluents), magnesium stearate (lubricant and non-stick) and talc (non-stick). However, in the prospectuses of the four pharmaceutical products analyzed, it was not reported which concentrations of these excipients were present in the medications in question, with only the abbreviation q.s. (quantum sufficit, i.e., sufficient amount of excipient used in each tablet). 
There are in the scientific literature toxicity assessment studies that demonstrated cytotoxicity and genotoxicity of some of these additive excipients. Among them, the study conducted by Sardi et al. (2010) verified that sunset yellow dye altered the turnover of rodent cells during the interphase, expressively inhibiting cell division. Still, Türkoğlu (2007) and Gomes et al. (2013) observed that such dye was cytogenotoxic to root meristem cells of $A$. cepa. In relation to the excipient titanium dioxide, Jain et al. (2017) tested this additive on Chinese hamster fibroblast (V79) by means of the comet assay, and found that such substance was significantly cytotoxic and genotoxic to the culture of cells evaluated. Likewise, Proquin et al. (2017) investigated the toxicity of this dye in culture of normal cells, Caco-2-cell line, through the micronucleus and comet assays, and found that such excipient caused significant number of chromosomal breaks and significant reduction of cell proliferation.

For the ethanol diluent, Ribeiro and Gaivão (2010) evaluated the potential genotoxic effect on Drosophila melanogaster L. by means of the comet assay, and reported that this bioassay when exposed to different concentrations of ethyl alcohol caused a significant reduction in cell division and expressive frequency of DNA damage at the level of neuroblasts. It is important to report that, according to Marek and Ktaft (2014), ethanol has been used for decades in neonatal, infant and adult medicines, but the pharmacokinetics, pharmacodynamics, and cytotoxicity of the drug are not yet well characterized, and the medications added with it should be used with caution. No cytotoxicity and genotoxicity studies were found in relation to the other excipients mentioned in the package inserts of the ginkgo products analyzed.

Thereby, the results of cellular toxicity of the mentioned excipients corroborate those obtained for the industrialized ginkgo evaluated in the present study, because they also caused genetic instability, mainly to the cell cycle of the bioassays in which they were evaluated. Thus, the results of cytotoxicity found herein indicate the need to evaluate the ginkgo pharmaceutical products, as well as the excipients present in these products, in animal testing systems, from treatments with longer exposure times, to verify and deepen the results obtained.

\section{CONCLUSIONS}

The results obtained in the present study showed that the ginkgo without additives was neither cytotoxic nor genotoxic to the root meristem tissue of A. cepa.

In turn, for the industrialized ginkgo, the three concentrations of the analyzed products were cytotoxic to the test system used.

Industrialized ginkgo products tested were not genotoxic to root meristem cells of A. cepa.

RESUMO: Avaliou-se, em células meristemáticas de raízes de Allium cepa, o potencial tóxico em nível celular de folhas de Ginkgo biloba L. industrializadas, nas concentrações 0,1;0,2 e 0,4 mg/mL. Os produtos industrializados, oriundos de quatro laboratórios farmacêuticos, foram identificados como A, B, C e D. Também avaliou-se a toxicidade em nível celular de chás de folhas de ginkgo desidratadas, nas concentrações 0,$15 ; 0,30$ e $0,60 \mathrm{mg} / \mathrm{mL}$. Os produtos desidratados foram adquiridos em ervanários certificados pela ANVISA. As raízes ficaram expostas aos chás e produtos industrializados por 24 e 48 horas. Os resultados obtidos foram submetidos ao teste Qui-quadrado, a 5\%. No entanto, os produtos de ginkgo industrializados, em todas as concentrações, causaram efeito antiproliferativo. Ainda, os produto adquiridos em farmácias não induziram alterações em número significativo aos meristemas de raízes. Portanto, os ginkgos industrializados promoveram citotoxicidade, porém, não foram genotóxicos frente ao bioensaio utilizado.

PALAVRAS-CHAVE: Ginkgo. Excipientes. Divisão celular. Alterações celulares. Tecido meristemático.

\section{REFERENCES}

AISSA, A. F.; BIANCHI, M. L. P.; RIBEIRO, J. C.; HERNANDES, L. C.; FARIA, A. F.; MERCADANTE, A.Z. Comparative study of $\beta$-carotene and microencapsulated $\beta$-carotene: Evaluation of their genotoxic and antigenotoxic effects. Food Chemical and Toxicology, Washington, v. 50, p. 1418-1424, 2012.

https://doi.org/10.1016/j.fct.2012.02.030 
BARROS A.; OLIVEIRA, L.; DELMASCHIO, D. A.; ANTUNES, C. R., CHEQUER, F. M. D. Corantes Alimentícios Amaranto, Eritrosina B e Tartrazina, e seus possíveis Efeitos Maléficos à Saúde Humana. Journal of Applied Pharmaceutical Sciences, Montes Claro, v. 2, n. 3, p. 16-30, 2015.

BRASIL. Agência Nacional de Vigilância Sanitária - ANVISA, 2007 [viewed 03 april 2016]. Resolucão da diretoria colegiada RDC no $\mathbf{0 5}$, de 15 de Janeiro de 2007. Brasília: ANVISA. Available from: http://www.anvisa.gov.br/legis/resol/2007/rdc/02_170107rdc.pdf

ELDER, D. P.; KUENTZ, M,; HOLM, R.. Pharmaceutical excipients-quality, regulatory and biopharmaceutical considerations. European Journal of Pharmaceutical Sciences, v. 87, p. 88-99, 2016. https://doi.org/10.1016/j.ejps.2015.12.018

GOMES, K. M. S.; OLIVEIRA, M. V. G. A.; CARVALHO, F. R. S.; MENEZES, C. C.; PERON, A. P. Citotoxicity of food dyes sunset yellow (E-110), bordeax red (E-123), and tatrazine yellow (E-102) on Allium cepa L. root meristematic cells. Food Science and Technology, Campinas, v. 33, p. 218-223, 2013. https://doi.org/10.1590/S0101-20612013005000012

GUERRA, M.; SOUZA, M. J. Como observar os cromossomos: um guia de técnicas em citogenética vegetal, animal e humana. Ribeirão Preto: FUNPEC, 2002. 340 p.

HAMZAWY, M. A., EL-DENSHARY, E. S., ABDEL-WAHHAB, M. A. (2015). Effects of natural compounds in treatment and prevention of hepatotoxicity and hepatocellular carcinoma. Hepatoma Research, Amsterdan, v. 1, p. 111-118, 2015. https://doi.org/10.4103/2394-5079.167378

HENG, K. Y.; KWAN, Y. H.; KOCHAR Handbook of cosmeceutical excipients and their safeties. Cambrigde: Elsevier:, 2014.

HERRERO, O.; MARTÍN, J. P.; FREIRE, P. F.; LÓPEZ, L. C.; PEROPADRE, A.; HAZEN, M. J. Toxicological evaluation of three contaminant of emerging concern by use of Allium cepa test. Mutation Reserch, Amsterdam, v. 743, p. 24-34, 2012. https://doi.org/10.1016/j.mrgentox.2011.12.028

JAIN, A. K.; SENAPATI, V. A.; SINGH, D.; DUBEY, K.; MAURYA, R.; PANDEY, A. K. Impact of anatase titanium dioxide nanoparticles on mutagenic and genotoxic response in Chinese hamster lung fibroblast cells (V-79): The role of cellular uptake. Food and Chemical Toxicology, 105, 127-139, 2017.

https://doi.org/10.1016/j.fct.2017.04.005

LACERDA, L. P.; MALAQUIAS, G.; PERON, A. P. Antiproliferative action of aqueous extracts of Mart. (Fabaceae) on the cell cycle of Allium cepa L. Anais da Academia Brasileira de Ciências, Rio de Janeiro, v. 86, p. 1147-1150, 2014.

LEME. D. M.; MARIN-MORALES, M. A. Chromossome aberration and micronucleis frequencies in A. cepa cells exposed to petroleum polluted water - a case study. Mutation Research, Amsterdam. v. 650, p. 80-86, 2008. https://doi.org/10.1016/j.mrgentox.2007.10.006

MAHMOUDIAN-SANI, M. R.; HASHEMZADEH-CHALESHTORI, M.; ASADI-SAMANI, M.; YANG, Q. Ginkgo biloba in the treatment of tinnitus: An updated literature review. The International Tinnitus Journal, Bethesda, v. 21, n. 1, p. 58-62, 2017. https://doi.org/10.5935/0946-5448.20170011

MAREK, E.; KRAFT, W. K. Ethanol pharmacokinetics in neonates and infants. Current Therapeutic Research, v. 76, p. 90-97, 2014. https://doi.org/10.1016/j.curtheres.2014.09.002

MARTINS, H. A.; PERON, A. P. Toxicidade de bebidas lácteas achocolatadas do tipo não fermentadas em tecido de intensa proliferação celular. Ciência e Natura, Santa Maria, v. 39, p. 33, 2016. https://doi.org/10.5902/2179460X23953 
MOURA, A. G.; SANTANA, G. M.; FERREIRA, P. M. P.; SOUSA, J. M. C.; PERON A. P. Cytotoxicity of Cheese and Cheddar Cheese food flavorings on Allim cepa L. root meristems. Brazilian Journal of Biology, São Carlos, v. 76, n. 2, p. 439-443, 2016. https://doi.org/10.1590/1519-6984.20514

NEVES, E. S.; FERREIRA, P. M. P.; LIMA, L. H.; PERON, A. P. Action of aqueous extracts of Phyllanthus niruri L. (Euphorbiaceae) leaves on meristematic root cells of Allium cepa L. Anais da Academia Brasileira de Ciências, Rio de Janeiro, v. 86, p. 1131-1137, 2014.

OLIVEIRA, D.; JOHANSSON, B.; OLIVEIRA, R. Ginkgo biloba, DNA Damage and DNA Repair: Overview. Handbook of Nutrition, Diet, and Epigenetics, 2017, p. 1-19, 2017.

OLIVEIRA, M. V. A.; ALVES, D. D. L.; LIMA, L. H. G. M.; CASTRO, J. M. C.; PERON, A. P. Cytotoxicity of erytrosine (E-127), brilliant blue (E-133) and red 40 (E-129) food dyes plant test system. Acta Scientiarum. Biological Science, Maringá, v. 5, p. 557-562, 2013.

PATRA, M.; PATNAIK, M.; BHATTACHARYA, S. Variation in impacto $\mathrm{f}$ use of diferente propellants and excipientes in pharmaceutical topical aerossol: Then and Now. Current Drug Delivery, 2017. Ahead of print.

POLANSKI, J. F.; SOARES, A. D.; CRUZ, O. L. Antioxidant therapy in the elderly with tinnitus. Brazilian Journal of Otorhinolaryngology, São Paulo, v. 82, n. 3, p. 269-274, 2016.

https://doi.org/10.1016/j.bjorl.2015.04.016

PROQUIN, H.; RODRÍGUEZ-IBARRA, C.; MOONEN, C. G.; URRUTIA ORTEGA, I. M. O., BRIEDÉ, J. J., DE KOK, T. M.; CHIRINO, Y. I. Titanium dioxide food additive (E171) induces ROS formation and genotoxicity: contribution of micro and nano-sized fractions. Mutagenesis, v. 32, n. 1, p. 139-149, 2016 https://doi.org/10.1093/mutage/gew051

RIBEIRO, I. P.; GAIVÃO, I. Efeito genotóxico do etanol em neuroblastos de Drosophila melanogaster. Revista Portuguesa de Saúde Pública, Lisboa, v. 28, n. 2, p. 199-204, 2010. https://doi.org/10.1016/S0870-9025(10)70011-0

SALES, I. M. S.; SANTOS, F. K. S.; FEITOZA, L. L.; SOUSA, J. M. C.; PERON, A. P. Toxicity at the cellular level of artificial synthetic flavorings. Acta Scientiarum. Biological Sciences, Maringá, v. 38, p. 297303, 2016.

SALES, I. M. S.; BARBOSA, J. S.; SANTOS, F. K. S.; SILVA, F. C. C.; FERREIRA, P. M. P.; PERON, A. P. Acute Toxicity of Grape, Plum and Orange Synthetic Food Flavourings Evaluated in in vivo Test Systems. Food Technology and Biotechnology, v. 55, n.1, p. 131-137, 2017. https://doi.org/10.17113/ftb.55.01.17.4770

SANTANA, G. M.; DEUS, M. S. M.; SOUSA, J. M. C.; FERREIRA, P. M. P.; FERNANDES, H. B.; PERON, A. P. Antimitotic and antimutagenic action of the Hymenaea stigonocarpa bark on dividing cells. Brazilian Journal of Biology, São Carlos, v. 76, p. 520 -525, 2016. https://doi.org/10.1590/1519-6984.23014

SARDI, M.; HALDEMANN, H.; NORDMANN, B.; BOTTEX, B.; SAFFORD, B.; SMITH, B.; TENNANT, D.; HOWLETT, J.; JASTI, P. R. (2010). Use of retailer fidelity card schemes in the assessment of food additive intake: sunset yellow a case study. Food Additives and Contaminants Part A, v. 27, n. 11, p. 1507-1515, 2010. https://doi.org/10.1080/19440049.2010.495728

VASCONCELOS, A. F. P.; ROLIM, L. A.; PEIXOTO, M. S. Influência dos excipientes multifuncionais no desempenho dos fármacos em formas farmacêuticas. Revista Brasileira de Farmacognosia, Curitiba, v. 93, n. 2, p. 136-145, 2012.

TURKEZ, H.; SOZIO, P.; GEYIKOGLU, F.; TATAR, A.; HACIMUFTUOGLU, A.; DI STEFANO, A. Neuroprotective effects of farnesene against hydrogen peroxide-induced neurotoxicity in vitro. Cellular and molecular neurobiology, Washington, v. 34, n. 1, p. 101-111, 2014. 
TÜRKOĞLU, Ş. Genotoxicity of five food preservatives tested on root tips of Allium cepa L. Mutation Research, Amsterdam, v. 626, p. 4-14, 2007. https://doi.org/10.1016/j.mrgentox.2006.07.006

WANG, S.; LI, D.; PI, J.; LI, W.; ZHANG, B.; QI, D.; LI, N.; GUO, P.; LIU, Z. Pharmacokinetic and ocular microdialysis study of oral Ginkgo biloba extract in rabbits by UPLC-MS/MS determination. Journal of Pharmacy and Pharmacology, 2017. Ahead of print. 